\title{
Strategies for blocking the fibrogenic actions of connective tissue growth factor (CCN2): From pharmacological inhibition in vitro to targeted siRNA therapy in vivo
}

\author{
David R. Brigstock
}

Received: 11 February 2009 /Accepted: 28 February 2009/Published online: 18 March 2009

(C) The Author(s) 2009. This article is published with open access at Springerlink.com

\begin{abstract}
Connective tissue growth factor (CCN2) is a major pro-fibrotic factor that frequently acts downstream of transforming growth factor beta (TGF- $\beta$ )-mediated fibrogenic pathways. Much of our knowledge of $\mathrm{CCN} 2$ in fibrosis has come from studies in which its production or activity have been experimentally attenuated. These studies, performed both in vitro and in animal models, have demonstrated the utility of pharmacological inhibitors (e.g. tumor necrosis factor alpha (TNF- $\alpha)$, prostaglandins, peroxisome proliferator-activated receptor-gamma (PPAR- $\gamma$ ) agonists, statins, kinase inhibitors), neutralizing antibodies, antisense oligonucleotides, or small interfering RNA (siRNA) to probe the role of $\mathrm{CCN} 2$ in fibrogenic pathways. These investigations have allowed the mechanisms regulating $\mathrm{CCN} 2$ production to be more clearly defined, have shown that $\mathrm{CCN} 2$ is a rational anti-fibrotic target, and have established a framework for developing effective modalities of therapeutic intervention in vivo.
\end{abstract}

Keywords CCN2 - Connective tissue growth factor. $\mathrm{CCN} 2 \cdot$ Transforming growth factor beta $\cdot$ TGF- $\beta$. Gene transcription · Fibrogenesis · Fibrosis · Therapeutic . Anti-fibrotic $\cdot$ Antisense $\cdot$ Neutralizing $\cdot$ SiRNA . Hepatic fibrosis $\cdot$ CTGF

D. R. Brigstock $(\square)$

The Research Institute at Nationwide Children's Hospital,

700 Children's Drive,

Columbus OH 43205, USA

e-mail: David.Brigstock@NationwideChildrens.org

D. R. Brigstock

Division of Pediatric Surgery, Department of Surgery,

The Ohio State University,

Columbus OH 43212, USA

\author{
Abbreviations \\ QSMA alpha smooth muscle actin \\ $\mathrm{CCl}_{4} \quad$ carbon tetrachloride \\ $\mathrm{CCN} 2$ connective tissue growth factor \\ COX cyclo-oxygenase \\ CVIR Collagen Type VI receptor \\ ECM extracellular matrix \\ HSC hepatic stellate cell \\ PG prostaglandin \\ PSC pancreatic stellate cell \\ RT-PCR reverse-transcriptase polymerase chain reaction \\ siRNA small interfering RNA \\ TGF- $\beta$ transforming growth factor beta \\ TIMP tissue inhibitor of metalloprotease \\ TNF- $\alpha$ tumor necrosis factor alpha
}

\section{Introduction}

Since the recognition almost 20 years ago that connective tissue growth factor $(\mathrm{CCN} 2)$ mRNA is induced in cultured fibroblasts by transforming growth factor beta (TGF- $\beta$ ) (Brunner et al. 1991), there has been a concerted effort to understand the mechanistic basis of this relationship and to explore its in vivo consequences (Leask and Abraham 2003; Shi-Wen et al. 2008; Leask et al. 2009). Nowhere is this more apparent than in the field of fibrosis, which currently represents the most common pathophysiology in which CCN2 has been implicated (Rachfal and Brigstock 2005) and in which there is an extensively documented role for TGF- $\beta$ as well (Verrecchia and Mauviel 2007). Fibrosis arises due to a failure of the normal wound healing response to terminate, leading to excessive scarring characterized by profound production, deposition, and contraction of extracellular matrix (ECM). This process usually occurs 
over many months and years, and can lead to organ dysfunction or death. Key observations have included the following: 1) CCN2 and TGF- $\beta$ are highly over-expressed and spatio-temporally correlated in numerous fibrotic lesions; 2) CCN2 induces the synthesis and secretion of ECM proteins, notably of fibrillar collagens which are a major component of fibrous deposits; and 3) TGF- $\beta$ mediated collagen synthesis in vitro is blocked by CCN2 antagonists. These observations have been complemented by a careful molecular dissection of the TGF- $\beta$-inductive axis and important response elements in the CCN2 promoter have now been identified that are involved in the regulation of CCN2 mRNA expression, although their relative contributions vary according to cell type (Shi-Wen et al. 2008; Leask et al. 2009).

On the other hand, it is important to be mindful of several caveats. Since CCN2 is a multi-modular matricellular protein, it probably resides in the ECM or tethered to the cell surface via integrins, heparan sulfate proteoglycans, and other receptors where it likely acts as a binding partner for other cell regulatory molecules (Chen and Lau 2008). Thus the pro-fibrotic properties of CCN2 may actually be a reflection of its ability to amplify fibrogenic responses to other factors. For example, a binding interaction between the CCN2 and TGF- $\beta$ proteins has been reported (Abreu et al. 2002) and this association may explain the synergistic interaction of these molecules in mouse models of dermal fibrosis whereas CCN2 alone is unable to drive sustained fibrosis (Frazier et al. 1996; Mori et al. 1999; Chujo et al. 2005). Also, there is no fibrosis in livers or kidneys of mice over-expressing tissue-specific CCN2 transgenes, yet the presence of the CCN2 transgene clearly exacerbates the population of pro-fibrogenic cell types, ECM deposition and/ or expression of fibrogenic markers after the organs undergo injury (Tong and Brigstock 2005; Yokoi et al. 2008). Thus while considerable data support a central role for CCN2 in fibrosis and its induction by TGF- $\beta$, we actually have a quite limited understanding of the various signaling events and molecular cross-talk that underlie its fibrogenic actions.

Fibrosis affects millions of people world-wide causing incalculable morbidity and mortality. In the USA it has been estimated that fibrosis of internal organs is a contributing factor in $45 \%$ of all deaths, yet there are currently no anti-fibrotics that have been approved for use by the US Food and Drug Administration. Nonetheless, prospects for effective anti-fibrotic therapies have improved rapidly in the last decade and are based on targeting key participants in fibrogenic cascades (Ghiassi-Nejad and Friedman 2008). Hence, it is not surprising that investigators have begun to address the potential therapeutic benefit of targeting CCN2 as an anti-fibrotic strategy (Blom et al. 2002; Leask et al. 2002). A particular attraction of this approach is that CCN2 acts downstream of TGF- $\beta$ so targeting strategies that focus on preventing CCN2 production or action would avoid potential interference with the important tumor-suppressive and immuno-modulatory actions that are the hallmark of TGF- $\beta$ function and which have complicated the targeting of TGF- $\beta$ itself.

This article describes the experimental strategies that have proven effective for blocking CCN2-mediated fibrogenic pathways in cell cultures or animal models and which support further investigations of anti-CCN2 therapy for treating or preventing fibrosis in humans.

\section{Pharmacological inhibitors}

Tumor necrosis factor alpha (TNF- $\alpha)$

$\mathrm{TNF}-\alpha$ is mainly recognized as a proinflammatory cytokine but it also has anti-fibrotic effects in vitro and in vivo (Leask and Abraham 2004) leading several investigators to analyze its effect on CCN2 expression. Thus, TNF- $\alpha$ was shown to reduce basal CCN2 expression in bovine aortic endothelial cells, fibroblasts and vascular smooth muscle cells (Dammeier et al. 1998; Lin et al. 1998) as well as in TGF- $\beta$-stimulated fibroblasts or airway smooth muscle cells (Abraham et al. 2000; Xie et al. 2005; Beddy et al. 2006), dexamethasome-stimulated Balb/c 3 T3 cells (Dammeier et al. 1998) or histamine-stimulated lung fibroblasts (Kunzmann et al. 2007). However, in pancreatic stellate cells (PSC) or mesangial cells, the effect of TNF- $\alpha$ was actually to stimulate CCN2 expression (Cooker et al. 2007; Karger et al. 2008) while it had no effect on constitutive CCN2 expression in scleroderma fibroblasts (Abraham et al. 2000) or glucose-stimulated CCN2 expression in peritoneal mesothelial cells (Sakamoto et al. 2005). While the anti-fibrotic actions of TNF- $\alpha$ were initially attributed to interference of TGF- $\beta$ pathways either by NF-kB-mediated induction of Smad7 or JNKmediated suppression of Smad 3 (Leask and Abraham 2004), the data now suggest that these pathways are overridden or inoperative under some circumstances in some cell types. Hence the use of TNF- $\alpha$ as a CCN2 inhibitor must therefore be carefully validated for each specific experimental system under investigation.

Prostaglandins (PG)

In fibroblasts, TGF- $\beta$ or TNF- $\alpha$ induce expression of cyclooxygenase-1 or -2 (COX-1, COX-2) respectively, which catalyze the production of $\mathrm{PG}$ from arachidonic acid. A well documented effect of PG in some systems is that of being anti-fibrotic, a property that is attributed to their activation of protein kinase $\mathrm{A}$ and elevation of intracellular cAMP levels (Leask and Abraham 2004). Indeed, early studies 
showed that cAMP blocking agents such as cholera toxin, forskolin or 8-Br-cAMP were effective in preventing TGF$\beta$-induced CCN2 production and anchorage-independent growth in NRK cells (Kothapalli et al. 1998). Forskolin also blocked CCN2 mRNA expression in TGF- $\beta$-stimulated human lung or renal mesangial cells (Black et al. 2007). Additionally, prostaglandin E2 (PGE2) inhibited TGF- $\beta$ stimulated $\mathrm{CCN} 2$ production in pulmonary fibroblasts or mesangial cells, glucose-induced CCN2 levels in kidney mesangial cells, or TGF- $\beta$-induced $\mathrm{CCN} 2$ production by airway smooth muscle cells or rat-1 cells, the latter of which was mediated via EP-2 receptors (Ricupero et al. 1999; Yu et al. 2002; Makino et al. 2003; Burgess et al. 2006; Black et al. 2007). Iloprost, a synthetic analogue of prostacyclin $\mathrm{PGI}_{2}$ that is used to help relieve Raynaud's phenomenon in scleroderma patients, elevates cAMP levels and antagonizes the ras/MEK/ERK signaling cascade necessary for induction of CCN2 (Stratton et al. 2001, 2002; Leask et al. 2003), and its inhibitory effect on CCN2 expression has been applied in an in vivo model of liver regeneration to demonstrate the CCN2-dependency of Thy$1+$ oval cell recruitment (Pi et al. 2005). The suppression of CCN2 or collagen production by 9-cis-retinoic acid in scleroderma fibroblasts is due to its induction of COX-2 and PGE2 expression (Xiao et al. 2008), while all-trans retinoic acid exerted anti-fibrotic effects in the liver and was associated with decreased CCN2 and TGF- $\beta$ production (Wang et al. 2008). Further, the involvement of ras/ $\mathrm{MEK} / \mathrm{ERK}$ in CCN2 expression has allowed these pathways to be explored with specific kinase inhibitors such as U0126 or PD98059 (Black et al. 2007; Pickles and Leask 2007; Leask et al. 2008).

It should be stressed that exceptions have been noted in how PG influences CCN2 expression in some experimental systems. For example, the action of PGF $2 \alpha$ in the cat iris is associated with increased CCN2 expression (Liang et al. 2003) while gingival fibroblasts are resistant to PGmediated CCN2 inhibition because the cAMP pathway is poorly coupled to the ras/MEK/ERK pathway and because PGE2 acts via the EP3 receptor to elevate JNK which opposes cAMP-mediated CCN2 inhibition (Black et al. 2007). Thus while PGs and their up- or down-stream mediators are often inhibitory for CCN2 expression, their actual effects must be experimentally validated to take account of cell- or tissuespecific variations in $\mathrm{PG}$ responses.

Peroxisome proliferator-activated receptor-gamma (PPAR- $\gamma$ ) agonists

PPAR- $\gamma$ is a nuclear receptor and a ligand-activated transcription factor that acts in adipocytes as a lipid sensor for fatty acids, eicosanoids, or their metabolites. However, experimental studies of PPAR- $\gamma$ using the natural ligand 15-deoxy- $\Delta^{12,14}$ prostaglandin $\mathrm{J}_{2}$ or synthetic ligands such as rosiglitazone, pioglitazone, or GW7845 have shown that PPAR- $\gamma$ acts in a variety of cell types where it can mediate suppression of basal or TGF- $\beta$-stimulated collagen synthesis in vitro or in vivo (Ghosh et al. 2004; Burgess et al. 2005; Milam et al. 2008). Accumulating data clearly shows that CCN2 is attenuated in many cell types upon stimulation of PPAR- $\gamma$. For example in activated hepatic stellate cells (HSC), TGF- $\beta$-mediated CCN2 expression was inhibited by PPAR- $\gamma$ (Sun et al. 2006), the effect of which was increased by treatment of the cells with curcumin which stimulated of PPAR- $\gamma$ expression (Zheng and Chen 2006). In vascular smooth muscle cells, PPAR- $\gamma$ inhibited TGF- $\beta$ - or angiotensin-induced CCN2 expression in smooth muscle cells via Smad-dependent mechanisms (Fu et al. 2001; Gao et al. 2007). Other in vitro experiments have shown that PPAR- $\gamma$ also inhibits CCN2 expression in renal tubular epithelial cells (Wei et al. 2007a, b), renal fibroblasts (Wang et al. 2007), and hepatocytes (Gressner et al. 2008), the latter of which was promoted by caffeine, suggesting its potential use as an anti-fibrotic (Gressner et al. 2008; Leask 2008). In vivo, administration of PPAR- $\gamma$ agonoists caused decreased CCN2 production in models of conjuctival scarring and lung injury (Aoki et al. 2008; Yamanaka et al. 2009).

\section{Statins}

Statins are a class of cholesterol-lowering drugs that acts by inhibiting HMG-CoA reductase, the rate-limiting enzyme of the mevalonate pathway of cholesterol biosynthesis. However they also have anti-inflammatory, anti-oxidant and immunomodulatory actions, and have also been shown to be anti-fibrotic in models of renal interstitial fibrosis in rats (Li et al. 2004; Vieira et al. 2005). Some of these anti-fibrotic effects may be due, at least in part, to the attentuation of CCN2 expression which has been documented in several different systems and in response to a variety of statins. In vitro, CCN2 expression was inhibited by treatment of mesangial cells, lung fibroblasts or renal fibroblats with simvastatin (Eberlein et al. 2001; GoppeltStruebe et al. 2001; Heusinger-Ribeiro et al. 2004; Watts and Spiteri 2004; Watts et al. 2005), renal fibroblasts or tenon fibroblasts with lovastatin (Eberlein et al. 2001; MeyerTer-Vehn et al. 2008), renal tubular epithelial cells with pravastatin (Wei et al. 2007a), normal rat kidney cells with fluvastatin (Ikeuchi et al. 2004), or rat cardiac fibroblasts with atorvastatin (Martin et al. 2005). Moreover, CCN2 expression is suppressed in various animal models undergoing statin treatment including fluvastatin-treated nephropathy (Song et al. 2004), cerivastatin-treated renal fibrosis (Koepke et al. 2007), atorvastatin-treated vascular fibrosis (Ruperez et al. 2007), pravastin-treated intestinal fibrosis (Haydont et al. 2007), or simvastatin-treated pulmonary fibrosis (Ou et al. 
2008). The inhibition of CCN2 expression by statins is attributable to their interference with the Rock-Rho signaling pathway (Eberlein et al. 2001; Watts and Spiteri 2004; Haydont et al. 2007; Ruperez et al. 2007) which has been recognized as a potential anti-fibrotic target (Moriyama and Nagatoya 2004).

Clearly, considerable data has been amassed regarding the pharmacological inhibition of CCN2 that has helped to understand the mechanisms up- or down-stream of CCN2 expression in normal and pathological processes, and it is possible that these findings will help to facilitate or justify the therapeutic use of these compounds for treating human fibrotic disease. On the other hand, these inhibitors generally do not act in a manner that is CCN2specific because they regulate multiple signaling pathways and gene transcription events of which CCN2 is but one component. This lack of specificity is thus a drawback when trying to definitively pin-point processes that are absolutely CCN2-dependent.

\section{Neutralizing antibodies that block CCN2 action}

Several CCN2 antibodies, generated by immunization of chickens, rabbits or mice with a variety of CCN2 proteins or peptides, have been reported to have neutralizing activity. These antibodies include the following: polyclonal chicken antibodies raised against full length human CCN2 (Kothapalli et al. 1997); polyclonal antibodies against synthetic peptides corresponding to the domain between module 3 and module 4 including anti-CCN2[244-256] (HDLEENIKKGKKC) raised in chicken (Safadi et al. 2003) and anti-CCN2[240-259] (RPCEADLEENIKKGKK CIRT) raised in rabbit (Shimo et al. 2001); two humanized monoclonal antibodies raised against recombinant human CCN2 with specificity for module 2 which have been termed "JMAb31" (human IgG2) and "FG-3019" (human IgG1k), the latter of which recognizes residues 142-157 (Aikawa et al. 2006; Shimo et al. 2006); and monoclonal antibodies generated by genetic immunization of mice with human CCN2 cDNA that are specific for module 2 or module 3 or module 4 (Ikawa et al. 2008).

In general, these antibodies are not widely available and in only a few instances have they been tested in systems that address the fibrogenic properties of CCN2. More often, they have been used to probe the role of CCN2 in other biological processes such as anchorage-independent growth, tumorigenesis, metastasis angiogenesis, osteogenesis, and chondrogenesis (Kothapalli et al. 1997; Shimo et al. 2001, 2006; Safadi et al. 2003; Aikawa et al. 2006; Dornhofer et al. 2006). Given the structural complexities of the CCN2 molecule, the presence of multiple functional sites (e.g. integrin-binding) in more than one module, its susceptibility for proteolytic cleavage into smaller bioactive forms, and the broad repertoire of binding partners for CCN2 (the requirement for which in its full spectrum of activities has not been systematically addressed) (Brigstock 1999; Chen and Lau 2008), it is possible that a "one-size-fits-all" blocking antibody may not be technically feasible or capable of yielding definitive data for all of the many different read-outs of CCN2 activity. Indeed, the extent to which any of the aforementioned antibodies prevent $\mathrm{CCN} 2$ from stimulating its respective target cells by specific blocking of one or more functional sites in the CCN2 molecule versus "non-specific" steric hindrance has not been reported. While the answer to this question may be inconsequential in terms of exerting a neutralizing effect per se, it is a critical if we are to understand mechanistically the components of CCN2mediated fibrogenic cascades.

While CCN2 neutralizing antibodies have been used in in vitro experiments to demonstrate $\mathrm{CCN} 2$-dependency of TGF- $\beta$-induced collagen production (Duncan et al. 1999; Blalock et al. 2003), there are only a handful of published reports that support their use in fibrosis research in vivo. FG-3019 has been reported to show efficacy in models of renal fibrosis in rodents (Flyvbjerg et al. 2004; Wang et al. 2004a) and is currently under evaluation for phase I trials of kidney or lung fibrosis in humans (Mageto et al. 2004; Adler et al. 2006). Also genetic immunization of human CCN2 cDNA in mice yielded several monoclonal antibodies that reduced TGF- $\beta$-dependent fibrosis and collagen deposition in a mouse skin model, the most potent of which was targeted to module 2 (Ikawa et al. 2008). Thus the published data obtained with neutralizing CCN2 antibodies are very limited but do provide evidence for a role of CCN2 in fibrosis. Nonetheless, while these data suggest that module 2 is highly immunogenic and is involved somehow in fibrosis (Aikawa et al. 2006; Shimo et al. 2006; Ikawa et al. 2008), we must be mindful of the fact that forms of CCN2 comprising either module 3 alone or module 4 alone are bioactive and fibrogenic (Gao et al. 2004; Gao and Brigstock 2004, 2005, 2006; Tong and Brigstock 2006). Clearly we have much to learn about the functional domains in CCN2 and how they act independently or inter-dependently to support or drive fibrosis.

The lack of readily accessible and/or validated CCN2 neutralizing antibodies represents a huge frustration in the field. To circumvent this problem, many investigators have instead focused on antagonism of CCN2 mRNA using complementary DNA or RNA sequences - for which the reagents have been easier to develop and validate among the various laboratories involved. Thus, the role of CCN2 mRNA expression in fibrogenic pathways and its TGF- $\beta$-dependency or -independency has been investigated successfully and extensively using CCN2 antisense oligonucleotides or small interfering RNA (siRNA). 


\section{In vitro use of CCN2 antisense oligonucleotides or siRNA}

The use of CCN2 antisense oligonucleotides has helped to establish the role of CCN2 in TGF- $\beta$-induced collagen production in several cell types such as kidney mesangial cells, normal rat kidney cells, corneal fibroblasts, and conjuctival fibroblasts (Duncan et al. 1999; Yokoi et al. 2001, 2002; Blalock et al. 2003; Kanemoto et al. 2003; Yamanaka et al. 2008). Similar in vitro studies have shown reduced collagen synthesis in scleroderma fibroblasts (Xiao et al. 2006), reduced ECM production in vascular smooth muscle cells (Liu et al. 2007), or antagonism of TGF- $\beta$ - stimulated collagen production in dermal fibroblasts, osteoblasts or rat HSC (Wang et al. 2004b; Arnott et al. 2007; Li et al. 2008) after treatment of the target cells with CCN2 siRNA. Plasmids expressing short hairpin RNA were shown to disrupt $\mathrm{CCN} 2$ gene expression in cultured rat HSC and to cause marked attenuation in the production of collagens III and IV, laminin, and hyaluronic acid (Yuhua et al. 2008). Finally, hammerhead ribozymes designed to cleave CCN2 mRNA blocked TGF- $\beta$-mediated proliferation of dermal fibroblasts (Blalock et al. 2004) as well as basal or TGF- $\beta$ stimulated collagen synthesis and entry into $S$ phase of human HSC (D.R.B and R. Gao, unpublished observations).

a
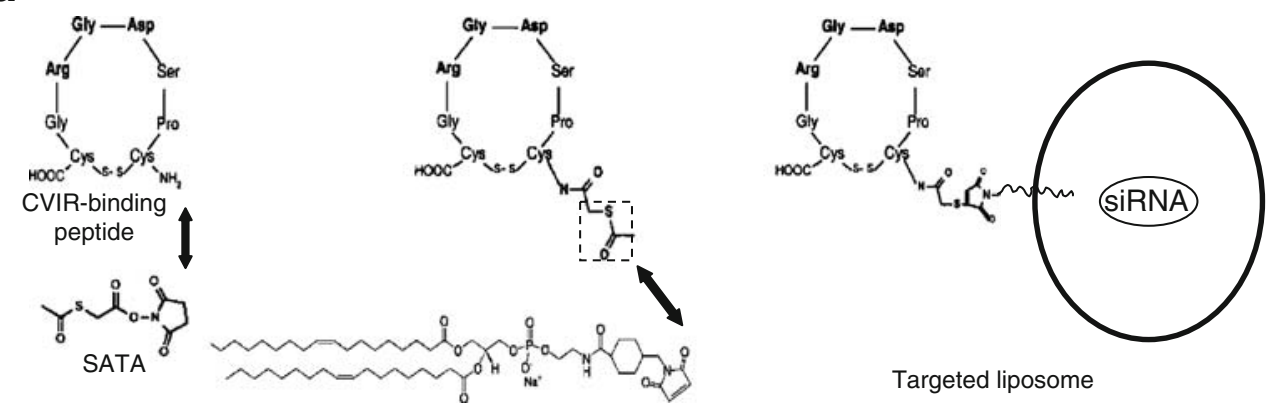

Targeted liposome

1,2-Dioleoyl-sn-Glycero-3-Phosphoethanolamine-N[4-(p-maleimidomethyl) cyclohexane-carboxamide] 18:1 PE-MCC

b

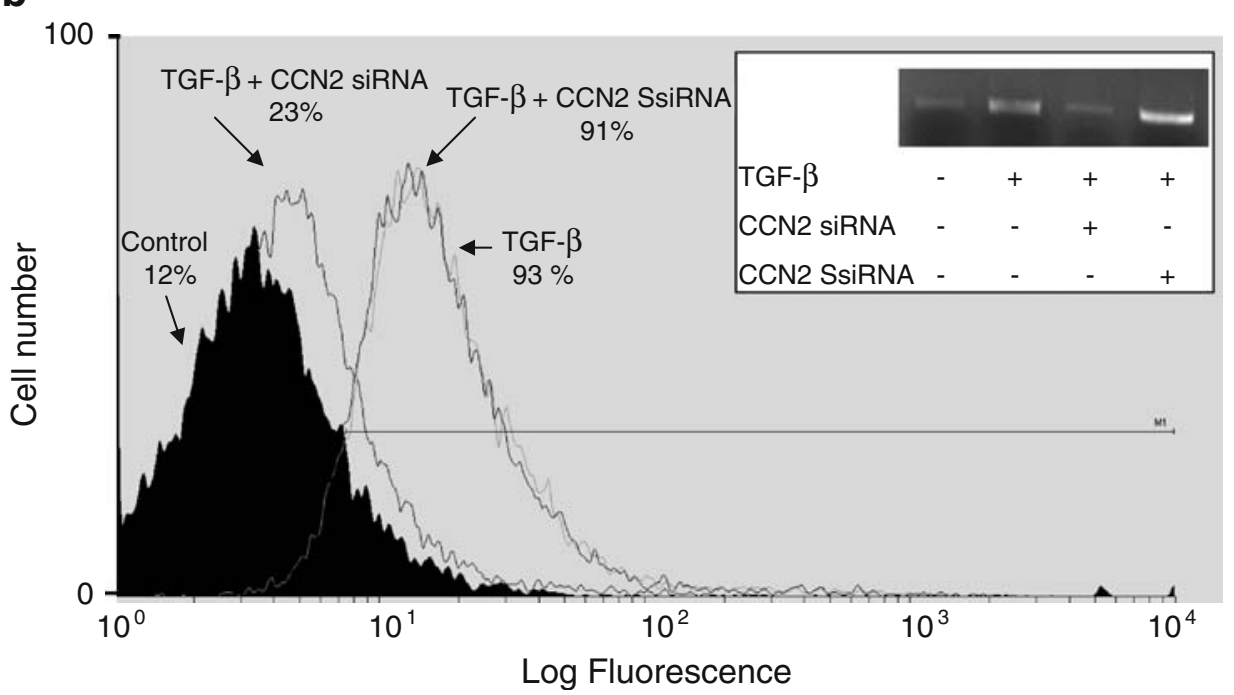

Fig. 1 a Production of targeted liposomes. A synthetic cyclic $\mathrm{C}^{*}$ GRGDSPC* peptide was modified at its free N-terminus with the bifunctional linker succinimidyl-S-acetylthioacetate (SATA), the thiol group of which allowed for subsequent coupling to a maleimide linker in a modified lipid formulation (1,2-dioleoyl-sn-Glycero-3Phosphoethanolamine-N-[4-(p-maleimidomethyl)cyclohexanecarboxamide]; 18:1 PE-MCC). Targeted liposomes were loaded with mouse CCN2 siRNA (sense: 5'-CCGCAAGAUUGGCGUGUGCtt; antisense: 5'-GCACACGCCAAUCUUGCGGtt; nucleotides 546-
566). b CCN 2 siRNA in targeted liposomes attenuates TGF- $\beta$ stimulated CCN2 production in mouse HSC in vitro. Day 2 primary mouse HSC were transfected for 6 hours with either $2 \mu \mathrm{M}$ CCN2 siRNA or scrambled siRNA (SsiRNA) using targeted lipsomes. On the next day, the cells were stimulated with $20 \mathrm{ng} / \mathrm{ml}$ TGF- $\beta$ for 24 hours and then analyzed for CCN2 protein or mRNA by, respectively, flow cytometry or RT-PCR (inset) as described (Leask et al. 2008; Lawrencia et al. 2009). CCN2 siRNA, but not SsiRNA, was effective in blocking TGF- $\beta$-induced CCN2 mRNA and protein 


\section{In vivo use of CCN2 antisense oligonucleotides or siRNA}

Several reports have supported the efficacy of anti-CCN2 mRNA strategies in treating hepatic fibrosis in vivo. In carbon tetrachloride $\left(\mathrm{CCl}_{4}\right)$-induced liver fibrosis in rats, subcutaneous administration of anti-sense CCN2 oligonucleotides resulted in decreased hepatic mRNA levels of $\mathrm{CCN} 2$ and collagen type I mRNA levels, although the amount of hepatic fibrosis was not actually reduced, possibly due to high expression of tissue inhibitor of metalloprotease


Fig. 2 Targeted CCN2 siRNA suppresses accumulation of $\alpha$ SMA or collagen deposition in preventative fibrosis model. Livers were sectioned and processed to detect $\alpha$ SMA (upper panel; brown stain) or collagen deposition (lower panel; blue stain) after administration of oil $\mathbf{a}$ or $\mathrm{CCl}_{4}$ for 3 weeks b-e, the latter 2 weeks of which were given concurrent with either no therapy $\mathbf{b}$, scrambled CCN2 siRNA in targeted liposomes $\mathbf{c}, \mathrm{CCN} 2$ siRNA in non-targeted liposomes d, or CCN2 siRNA in targeted liposomes (E). $\mathrm{CCl}_{4}$ was given i.m. as four $30 \mu \mathrm{l}$ doses $\left(1: 1 \mathrm{CCl}_{4}\right.$ : olive oil) per week. siRNA treatments $(0.1 \mathrm{mg} / \mathrm{kg})$ were given 4 times a week by i.p. injection. The staining intensity was assessed by image analysis ( 50 sections; 10 sections from each of 5 mice) and is shown in the bar graph. Data shown are indicative of the data from 3 separate experiments 
(TIMP)-1 (Uchio et al. 2004). On the other hand, intraportal vein injection of $\mathrm{CCN} 2$ siRNA in $\mathrm{CCl}_{4}$-treated rats reduced hepatic expression of CCN2, collagen Types 1, 2, 3, laminin, TIMP-1, and TGF- $\beta$, reduced the number of activated HSC as assessed by $\alpha \mathrm{SMA}$ staining, and further reduced serum procollagen Type 3, hepatic hydroxyproline and liver fibrosis staging (Li et al. 2006). A very similar improvement was also seen in N-nitrosodimethylamine-induced hepatic fibrosis in
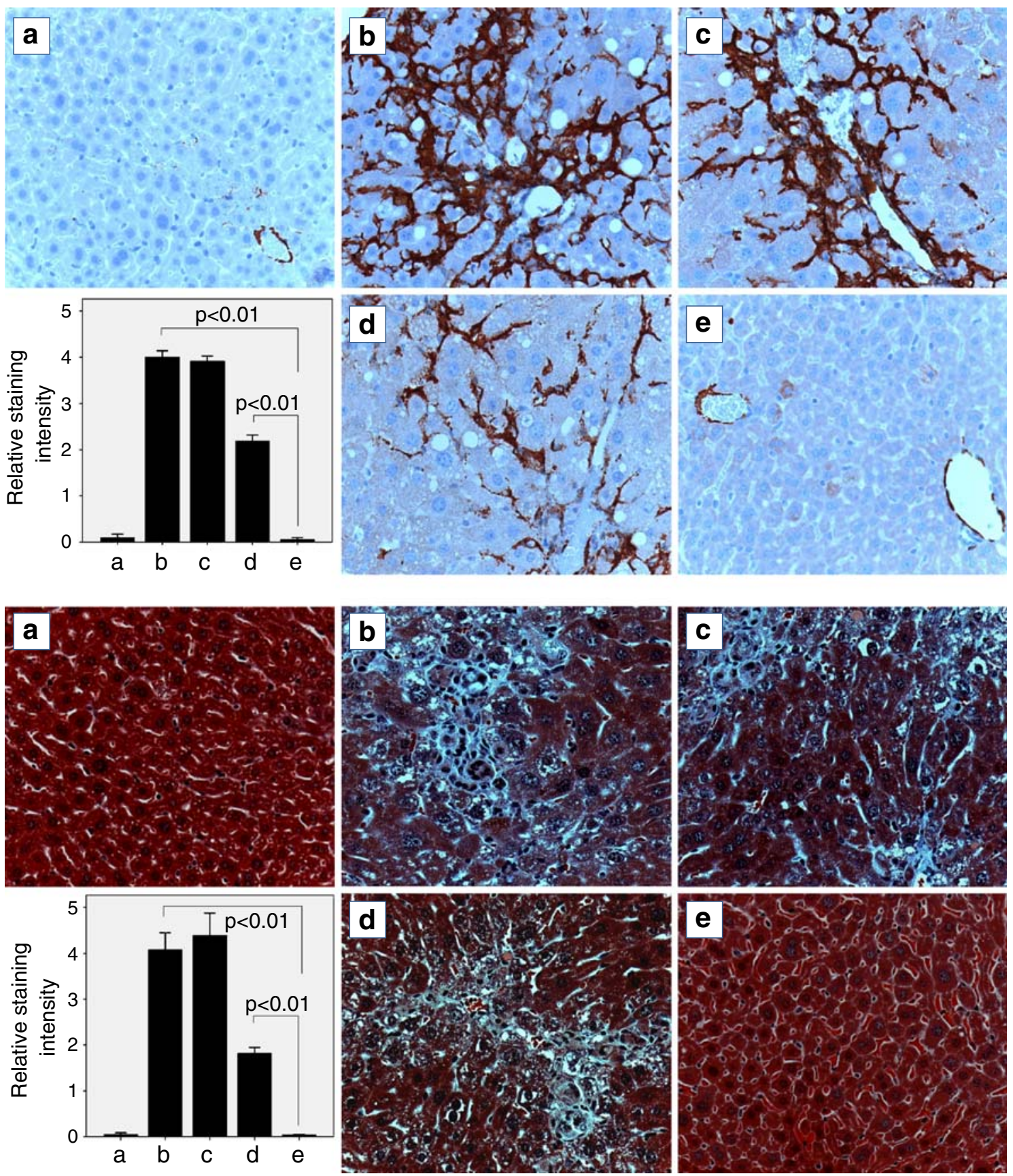

Fig. 3 Targeted CCN2 siRNA prevents accumulation of $\alpha$ SMA or collagen deposition in curative fibrosis model Livers were sectioned and processed to detect $\alpha$ SMA (upper panel; brown stain) or collagen deposition (lower panel; blue stain) after administration of oil a or $\mathrm{CCl}_{4}$ for 5 weeks b-e, the latter 2 weeks of which were given concurrent with either no therapy $\mathbf{b}$, scrambled CCN2 siRNA in targeted liposomes c, CCN2 siRNA in non-targeted liposomes d, or
CCN2 siRNA in targeted liposomes e. $\mathrm{CCl}_{4}$ was given i.m. as four $30 \mu \mathrm{l}$ doses $\left(1: 1 \mathrm{CCl}_{4}\right.$ :olive oil) per week. siRNA treatments $(0.1 \mathrm{mg} / \mathrm{kg})$ were given 4 times a week by i.p. injection. The staining intensity was assessed by image analysis ( 50 sections; 10 sections from each of 5 mice) and is shown in the bar graph. Data shown are indicative of the data from 3 separate experiments 
rats for which CCN2 siRNA was found to be effective in both preventative and curative fibrosis models (George and Tsutsumi 2007).

Similar outcomes have been reported in other model systems, most notably for kidney fibrosis. For example, in a unilateral ureteral obstruction model of renal fibrosis in the rat, blocking the activity of CCN2 by antisense oligonucleotides reduced the induction of CCN2 and, in turn, ECM genes and their corresponding proteins (Yokoi et al. 2004). CCN2 antisense oligonucleotides also significantly blocked CCN2 expression and renal interstitial fibrogenesis in a remnant kidney model of sub-totally nephrectomized mice transgenic for TGF- $\beta$, despite sustained expression of TGF$\beta$ (Okada et al. 2005). Other in vivo studies have shown that CCN2 siRNA delivery to rats is an effective antifibrotic therapy in renal allografts after transplantation (Luo et al. 2008). Finally, CCN2 antisense oligonucleotides have proven effective in reducing ECM expansion and scarring around breast implants (Mazaheri et al. 2003).

Clearly, we have witnessed the advent of an era in which unequivocal anti-fibrotic effects can be achieved by blocking CCN2 mRNA in vivo. This line of investigation is undoubtedly in its infancy but shows great promise in that some remarkable and reproducible therapeutic effects have been reported despite the use of different model systems.

\section{New data from the author's laboratory: Targeted CCN2 mRNA silencing in vivo}

Previous studies have shown that the cyclic peptide C*GRGDSPC*, which selectively binds to collagen Type VI receptors (CVIR) on activated HSC (Marcelino and
McDevitt 1995), can be used as a homing device to target to HSC in fibrotic livers (Beljaars et al. 2000). This approach has attracted attention because it provides for a targeting strategy whereby anti-fibrotic agents can be delivered more efficiently to the highly pro-fibrotic HSC despite their relatively low abundance. Recently, it was reported that delivery of interferon- $\alpha 1 \mathrm{~b}$ in liposomes coated with a slightly modified form of the CVIR-binding peptide was delivered highly efficiently to activated HSC in vivo and was anti-fibrotic in a bile duct ligation model of liver fibrosis in rats (Du et al. 2007). In concurrent experiments performed in this laboratory, a CVIR-binding cyclic peptide was covalently bound to the surface of modified liposomes (Fig. 1a) and used for delivery of CCN2 siRNA in mouse models of $\mathrm{CCl}_{4}$-induced liver fibrosis (Lawrencia and Brigstock 2008). Prior to performing the in vivo experiments, the efficacy of the targeted liposomes in reducing CCN2 mRNA expression and protein production in primary mouse HSC was verified by reverse-transcriptase polymerase chain reaction (RT-PCR) and flow cytometry (Fig. 1b). For in vivo studies, Balb/c mice received an i.m. injection of $\mathrm{CCl}_{4}$ on four consecutive days each week for either 1 week (preventative model) or 3 weeks (curative model). For the next 2 weeks, mice continued to receive $\mathrm{CCl}_{4}$ under the same dosing regimen plus mouse CCN2 siRNA which was delivered 4 times a week by i.p. injection, in either targeted or non-targeted liposomes. Control mice received either oil instead of $\mathrm{CCl}_{4}$ or a scrambled CCN2 siRNA sequence in the targeted liposomes.

In both the preventative (Fig. 2) and curative (Fig. 3) models, immunohistochemical staining for $\alpha$ SMA (a marker of activated HSC) and trichrome staining for collagen revealed very low levels of each molecule in control oil-
Fig. 4 Expression of fibrosisrelated genes. Livers were removed from mice after administration of oil a or $\mathrm{CCl}_{4} \mathbf{b}$-e for 3 weeks (preventative model; upper panel) or 5 weeks (curative model; lower panel). For the last 2 weeks in each model mice received no therapy b, scrambled CCN2 siRNA in targeted liposomes c, CCN2 siRNA in non-targeted liposomes $\mathbf{d}$ or CCN2 siRNA in targeted liposomes e. RNA was isolated and subjected to RTPCR to establish the expression level of the indicated fibrotic marker genes as described (Lawrencia et al. 2009). Data are plotted relative to the expression of $\beta$-actin

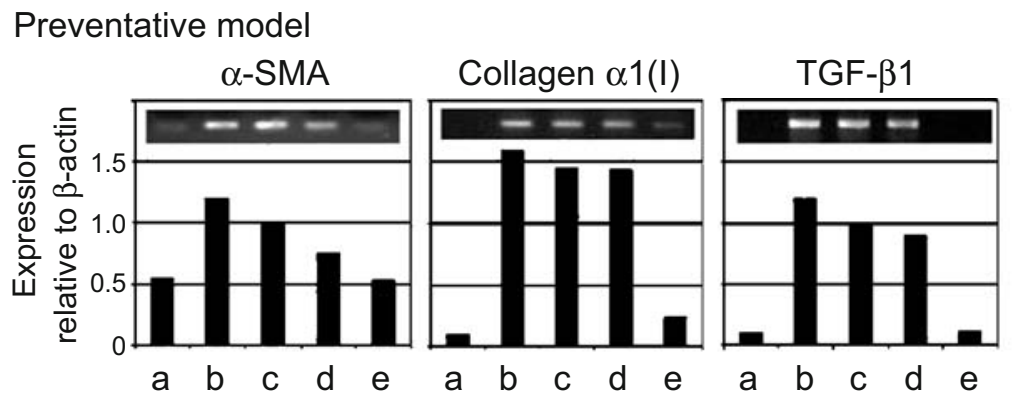

Curative model

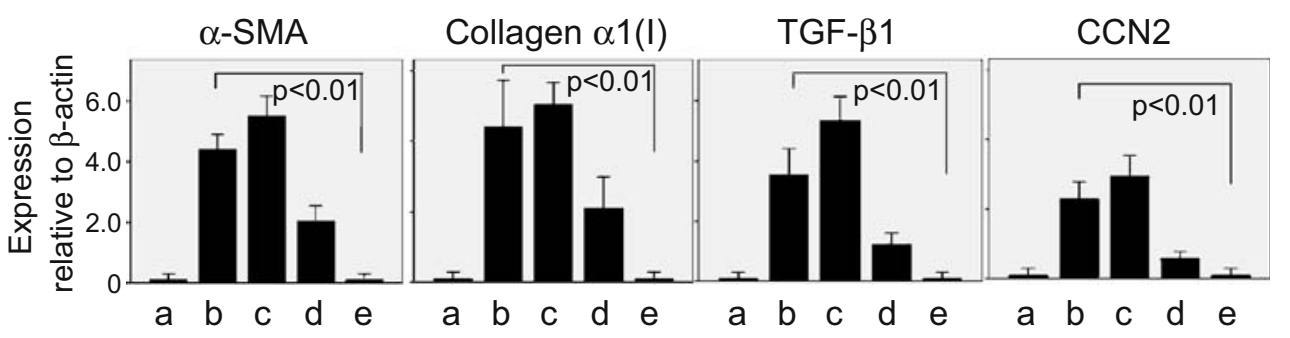


treated animals (Figs 2, 3, panel a) and massive amounts of $\alpha \mathrm{SMA}$ and collagen (bridging fibrosis) in response to $\mathrm{CCl}_{4}$ (Figs 2, 3, panel b) as expected. This staining pattern remained unaltered in the presence of targeted scrambled CCN2 siRNA (Figs 2, 3, panel c). The $\mathrm{CCl}_{4}$-induced levels of $\alpha \mathrm{SMA}$ and collagen were diminished by nontargeted antisense CCN2 siRNA (Figs 2, 3, panel d) but the targeted antisense CCN2 siRNA approach was considerably more efficacious in that $\alpha$ SMA and collagen levels were reduced to background levels (Figs 2, 3, panel e) and essentially indistinguishable from those of oil treated animals.

As assessed by RT-PCR, the expression of key fibrotic markers was strongly attenuated by the targeted CCN2 therapy in both fibrosis models. The data for the preventative and curative models (Fig. 4) showed that the transcript levels for collagen $\alpha 1(\mathrm{I}), \alpha \mathrm{SMA}$, TGF- $\beta$, or CCN2 were highly induced by $\mathrm{CCl}_{4}$ treatment as expected. These expression levels remained high in the presence of targeted scrambled CCN2 siRNA as expected and were only modestly reduced by the non-targeted CCN2 siRNA. However, the targeted CCN2 siRNA caused the mRNA levels of collagen $\alpha 1(\mathrm{I}), \alpha \mathrm{SMA}, \mathrm{TGF}-\beta$ or $\mathrm{CCN} 2$ to be reduced to background levels and were therefore indistinguishable from oil-treated controls. These data were thus consistent with the histological findings in each model (Figs 2, 3)

On the one hand, these data show that non-targeted liposomes carrying CCN2 siRNA do exhibit therapeutic efficacy as also recently demonstrated in N-nitrosodimethylamineinduced hepatic fibrosis in rats (George and Tsutsumi 2007), and this presumably reflects the fact that the liver is one of the principal organs in which liposomes tend to accumulate after injection (Ostro and Cullis 1989). On the other hand, the targeted liposomes were more effective than non-targeted liposomes in either preventing or reversing fibrosis and attenuating expression of fibrosis-related genes even in the continued presence of the fibrotic insult. While these findings reinforce a central role for $\mathrm{CCN} 2$ hepatic fibrosis, the fact that higher levels of CVIR are produced by HSC in fibrotic injury and were the presumptive binding site for the targeted peptide in these studies suggest that CCN2 of HSC origin may be particularly important in driving hepatic fibrosis in vivo. The data additionally highlight the potential versatility of using targeted liposomes to deliver other therapeutic siRNAs to HSC in injured liver. Indeed, a similar system was recently described in which vitamin A-coated liposomes were shown to preferentially bind to HSC and to reverse acute and chronic fibrosis and prolong survival in rats upon delivery of siRNA to rat gp46, a collagen chaperone that is homologous to human heat shock protein 47 (Sato et al. 2008). Targeted strategies have also been described for other organ systems such as the kidney
(Prakash et al. 2008) but it is uncertain whether this degree of sophistication will in fact be necessary for the successful implementation of anti-fibrotic therapy in humans (Friedman 2008).

\section{Conclusions}

A variety of CCN2 antagonistic strategies have been developed in numerous experimental systems that demonstrate a central role for $\mathrm{CCN} 2$ in fibrogenesis and which, in turn, have shown that targeting of CCN2 expression or action is a rational therapeutic approach in fibrotic pathologies. A diverse repertoire of techniques has been described that are effective in blocking CCN2 but it is important to appreciate their individual limitations and to be mindful of alternative approaches for studying CCN2 mechanisms. For example, CCN2-null mice are amenable to elegant exploration of CCN2-dependent pathways in vivo (Ivkovic et al. 2003; Chuva de Sousa Lopes et al. 2004; Kuiper et al. 2007, 2008; Nishida et al. 2007; Kawaki et al. $2008 \mathrm{a}, \mathrm{b})$, and the analysis of specific cell types derived from these CCN2-deficient animals hold promise for further definition of CCN2-dependent mechanisms in vitro, including those related to fibrosis (Chen et al. 2004; Shi-wen et al. 2006; Kennedy et al. 2007; Kawaki et al. 2008a; Mori et al. 2008; Pala et al. 2008; Crawford et al. 2009). Nonetheless, the ability to attenuate CCN2 production in fibrotic tissues remains a reasonable and realistic goal. With respect to antifibrotic strategies in humans, the challenges ahead will be to establish which fibrotic pathologies, if any, are best suited to CCN2 targeting (possibly in combination with targeting of other fibrogenic mediators) and to determine the optimal form(s) that this therapy should take.

Acknowledgements DRB was supported by the Ben Bryer Trust and NIH grants 5R01AA016003 and 5R01AA015554.

Open Access This article is distributed under the terms of the Creative Commons Attribution Noncommercial License which permits any noncommercial use, distribution, and reproduction in any medium, provided the original author(s) and source are credited.

\section{References}

Abraham DJ, Shiwen X, Black CM, Sa S, Xu Y, Leask A (2000) Tumor necrosis factor alpha suppresses the induction of connective tissue growth factor by transforming growth factorbeta in normal and scleroderma fibroblasts. J Biol Chem 275:15220-15225. doi:10.1074/jbc.275.20.15220

Abreu JG, Ketpura NI, Reversade B, De Robertis EM (2002) Connective-tissue growth factor (CTGF) modulates cell signalling by BMP and TGF-beta. Nat Cell Biol 4:599-604 
Adler SG, Schwartz SM, Williams ME, Arauz-Pacheco C, Bolton WK, Lee TH, Coker G, Sewell KL (2006) Dose-escalation phase I study of FG-3019, anti-CTGF monoclonal antibody, in patients with type 1/2 diabetes mellitus and microalbuminuria. J Am Soc Nephrol 17:157A. doi:10.1681/ASN.2006111191

Aikawa T, Gunn J, Spong SM, Klaus SJ, Korc M (2006) Connective tissue growth factor-specific antibody attenuates tumor growth, metastasis, and angiogenesis in an orthotopic mouse model of pancreatic cancer. Mol Cancer Ther 5:1108-1116. doi:10.1158/ 1535-7163.MCT-05-0516

Aoki Y, Maeno T, Aoyagi K, Ueno M, Aoki F, Aoki N, Nakagawa J, Sando Y, Shimizu Y, Suga T, Arai M, Kurabayashi M (2008) Pioglitazone, a Peroxisome Proliferator-Activated Receptor Gamma Ligand, Suppresses Bleomycin-Induced Acute Lung Injury and Fibrosis. Respiration. doi:10.1159/000168676

Arnott JA, Nuglozeh E, Rico MC, Arango-Hisijara I, Odgren PR, Safadi FF, Popoff SN (2007) Connective tissue growth factor (CTGF/CCN2) is a downstream mediator for TGF-beta1-induced extracellular matrix production in osteoblasts. J Cell Physiol 210:843-852. doi:10.1002/jcp. 20917

Beddy D, Mulsow J, Watson RW, Fitzpatrick JM, O'Connell PR (2006) Expression and regulation of connective tissue growth factor by transforming growth factor beta and tumour necrosis factor alpha in fibroblasts isolated from strictures in patients with Crohn's disease. Br J Surg 93:1290-1296. doi:10.1002/bjs.5431

Beljaars L, Molema G, Schuppan D, Geerts A, De Bleser PJ, Weert B, Meijer DK, Poelstra K (2000) Successful targeting to rat hepatic stellate cells using albumin modified with cyclic peptides that recognize the collagen type VI receptor. J Biol Chem 275:1274312751. doi:10.1074/jbc.275.17.12743

Black SA Jr, Palamakumbura AH, Stan M, Trackman PC (2007) Tissue-specific mechanisms for CCN2/CTGF persistence in fibrotic gingiva: interactions between cAMP and MAPK signaling pathways, and PGE2-EP3 receptor mediated activation of the c-jun-N-terminal kinase. J Biol Chem 282:15416-15429. doi:10.1074/jbc.M610432200

Blalock TD, Duncan MR, Varela JC, Goldstein MH, Tuli SS, Grotendorst GR, Schultz GS (2003) Connective tissue growth factor expression and action in human corneal fibroblast cultures and rat corneas after photorefractive keratectomy. Invest Ophthalmol Vis Sci 44:1879-1887. doi:10.1167/iovs.02-0860

Blalock TD, Yuan R, Lewin AS, Schultz GS (2004) Hammerhead ribozyme targeting connective tissue growth factor mRNA blocks transforming growth factor-beta mediated cell proliferation. Exp Eye Res 78:1127-1136. doi:10.1016/j.exer.2004.01.012

Blom IE, Goldschmeding R, Leask A (2002) Gene regulation of connective tissue growth factor: new targets for antifibrotic therapy? Matrix Biol 21:473-482. doi:10.1016/S0945-053X(02) 00055-0

Brigstock DR (1999) The connective tissue growth factor/cysteinerich 61/nephroblastoma overexpressed $(\mathrm{CCN})$ family. Endocr Rev 20:189-206. doi:10.1210/er.20.2.189

Brunner A, Chinn J, Neubauer M, Purchio AF (1991) Identification of a gene family regulated by transforming growth factor- beta. DNA Cell Biol 10:293-300

Burgess HA, Daugherty LE, Thatcher TH, Lakatos HF, Ray DM, Redonnet M, Phipps RP, Sime PJ (2005) PPARgamma agonists inhibit TGF-beta induced pulmonary myofibroblast differentiation and collagen production: implications for therapy of lung fibrosis. Am J Physiol Lung Cell Mol Physiol 288:L1146L1153. doi:10.1152/ajplung.00383.2004

Burgess JK, Oliver BG, Poniris MH, Ge Q, Boustany S, Cox N, Moir LM, Johnson PR, Black JL (2006) A phosphodiesterase 4 inhibitor inhibits matrix protein deposition in airways in vitro. J Allergy Clin Immunol 118:649-657. doi:10.1016/j.jaci. 2006.05.019
Chen CC, Lau LF (2008) Functions and mechanisms of action of $\mathrm{CCN}$ matricellular proteins. Int $\mathrm{J}$ Biochem Cell Biol. doi:10.1016/j.biocel.2008.1007.1025

Chen Y, Abraham DJ, Shi-Wen X, Pearson JD, Black CM, Lyons KM, Leask A (2004) CCN2 (Connective Tissue Growth Factor) Promotes Fibroblast Adhesion to Fibronectin. Mol Biol Cell 15:5635-5646. doi:10.1091/mbc.E04-06-0490

Chujo S, Shirasaki F, Kawara S, Inagaki Y, Kinbara T, Inaoki M, Takigawa M, Takehara K (2005) Connective tissue growth factor causes persistent proalpha2(I) collagen gene expression induced by transforming growth factor-beta in a mouse fibrosis model. J Cell Physiol 203:447-456. doi:10.1002/jcp. 20251

Chuva de Sousa Lopes SM, Feijen A, Korving J, Korchynskyi O, Larsson J, Karlsson S, ten Dijke P, Lyons KM, Goldschmeding R, Doevendans P, Mummery CL (2004) Connective tissue growth factor expression and Smad signaling during mouse heart development and myocardial infarction. Dev Dyn 231:542-550. doi:10.1002/dvdy.20162

Cooker LA, Peterson D, Rambow J, Riser ML, Riser RE, Najmabadi F, Brigstock D, Riser BL (2007) TNF-alpha, but not IFN-gamma, Regulates CCN2 (CTGF), Collagen Type I, and Proliferation in Mesangial Cells: Possible Roles in the Progression of Renal Fibrosis. Am J Physiol Renal Physiol 293:F157-F165. doi:10.1152/ ajprenal.00508.2006

Crawford LA, Guney MA, Oh YA, Deyoung RA, Valenzuela DM, Murphy AJ, Yancopoulos GD, Lyons KM, Brigstock DR, Economides A, Gannon M (2009) Connective tissue growth factor (CTGF) inactivation leads to defects in islet cell lineage allocation and beta cell proliferation during embryogenesis. Mol Endocrinol. doi:10.1210/me.2008-0045

Dammeier J, Beer HD, Brauchle M, Werner S (1998) Dexamethasone is a novel potent inducer of connective tissue growth factor expression. Implications for glucocorticoid therapy. J Biol Chem 273:18185-18190. doi:10.1074/jbc.273.29.18185

Dornhofer N, Spong S, Bennewith K, Salim A, Klaus S, Kambham N, Wong C, Kaper F, Sutphin P, Nacalumi R, Hockel M, Le Q, Longaker M, Yang G, Koong A, Giaccia A (2006) Connective tissue growth factor-specific monoclonal antibody therapy inhibits pancreatic tumor growth and metastasis. Cancer Res 66:5816-5827. doi:10.1158/0008-5472.CAN-06-0081

Du SL, Pan H, Lu WY, Wang J, Wu J, Wang JY (2007) Cyclic ArgGly-Asp peptide-labeled liposomes for targeting drug therapy of hepatic fibrosis in rats. J Pharmacol Exp Ther 322:560-568. doi:10.1124/jpet.107.122481

Duncan MR, Frazier KS, Abramson S, Williams S, Klapper H, Huang X, Grotendorst GR (1999) Connective tissue growth factor mediates transforming growth factor beta-induced collagen synthesis: down-regulation by cAMP. FASEB J 13:1774-1786

Eberlein M, Heusinger-Ribeiro J, Goppelt-Struebe M (2001) Rhodependent inhibition of the induction of connective tissue growth factor (CTGF) by HMG CoA reductase inhibitors (statins). Br J Pharmacol 133:1172-1180. doi:10.1038/sj.bjp. 0704173

Flyvbjerg A, Khatir D, Jensen JN, Lomongsod E, Liu DY, Rasch R, Usinger WR (2004) Long-Term Renal Effects of a Neutralizing Connective Tissue Growth Factor (CTGF)- Antibody in Obese Type 2 Diabetic Mice. J Am Soc Nephrol 15:261A. doi:10.1097/ 01.ASN.0000107560.80107.19

Frazier K, Williams S, Kothapalli D, Klapper H, Grotendorst GR (1996) Stimulation of fibroblast cell growth, matrix production, and granulation tissue formation by connective tissue growth factor. J Invest Dermatol 107:404-411. doi:10.1111/1523-1747. ep12363389

Friedman SL (2008) Targeting siRNA to arrest fibrosis. Nat Biotechnol 26:399-400. doi:10.1038/nbt0408-399

Fu M, Zhang J, Zhu X, Myles DE, Willson TM, Liu X, Chen YE (2001) Peroxisome proliferator-activated receptor gamma inhibits 
transforming growth factor beta-induced connective tissue growth factor expression in human aortic smooth muscle cells by interfering with Smad3. J Biol Chem 276:45888-45894. doi:10.1074/jbc.M105490200

Gao DF, Niu XL, Hao GH, Peng N, Wei J, Ning N, Wang NP (2007) Rosiglitazone inhibits angiotensin II-induced CTGF expression in vascular smooth muscle cells - role of PPAR-gamma in vascular fibrosis. Biochem Pharmacol 73:185-197. doi:10.1016/ j.bcp. 2006.09.019

Gao R, Ball DK, Perbal B, Brigstock DR (2004) Connective tissue growth factor induces c-fos gene activation and cell proliferation through p44/42 MAP kinase in primary rat hepatic stellate cells. J Hepatol 40:431-438. doi:10.1016/j.jhep. 2003.11.012

Gao R, Brigstock DR (2004) Connective tissue growth factor (CCN2) induces adhesion of rat activated hepatic stellate cells by binding of its C-terminal domain to integrin alphavbeta3 and heparan sulfate proteoglycan. J Biol Chem 279:8848-8855. doi:10.1074/ jbc.M313204200

Gao R, Brigstock DR (2005) Connective tissue growth factor (CCN2) in rat pancreatic stellate cell function: integrin alpha5beta1 as a novel CCN2 receptor. Gastroenterology 129:1019-1030. doi:10.1053/j.gastro.2005.06.067

Gao R, Brigstock DR (2006) A novel integrin alpha5betal binding domain in module 4 of connective tissue growth factor (CCN2/ CTGF) promotes adhesion and migration of activated pancreatic stellate cells. Gut 55:856-862. doi:10.1136/gut.2005.079178

George J, Tsutsumi M (2007) siRNA-mediated knockdown of connective tissue growth factor prevents N-nitrosodimethylamine-induced hepatic fibrosis in rats. Gene Ther 14:790-803. doi:10.1038/sj. gt.3302929

Ghiassi-Nejad Z, Friedman SL (2008) Advances in antifibrotic therapy. Expert Rev Gastroenterol Hepatol 2:803-816

Ghosh AK, Bhattacharyya S, Lakos G, Chen SJ, Mori Y, Varga J (2004) Disruption of transforming growth factor beta signaling and profibrotic responses in normal skin fibroblasts by peroxisome proliferator-activated receptor gamma. Arthritis Rheum 50:1305-1318. doi:10.1002/art.20104

Goppelt-Struebe M, Hahn A, Iwanciw D, Rehm M, Banas B (2001) Regulation of connective tissue growth factor $(\operatorname{ccn} 2$; $\operatorname{ctgf})$ gene expression in human mesangial cells: modulation by HMG CoA reductase inhibitors (statins). Mol Pathol 54:176-179. doi: $10.1136 / \mathrm{mp}$. 54.3.176

Gressner OA, Lahme B, Rehbein K, Siluschek M, Weiskirchen R, Gressner AM (2008) Pharmacological application of caffeine inhibits TGF-beta-stimulated connective tissue growth factor expression in hepatocytes via PPARgamma and SMAD2/3dependent pathways. J Hepatol 49:758-767. doi:10.1016/j.jhep. 2008.03.029

Haydont V, Bourgier C, Pocard M, Lusinchi A, Aigueperse J, Mathe D, Bourhis J, Vozenin-Brotons MC (2007) Pravastatin Inhibits the $\mathrm{Rho} / \mathrm{CCN} 2 /$ extracellular matrix cascade in human fibrosis explants and improves radiation-induced intestinal fibrosis in rats. Clin Cancer Res 13:5331-5340. doi:10.1158/1078-0432. CCR-07-0625

Heusinger-Ribeiro J, Fischer B, Goppelt-Struebe M (2004) Differential effects of simvastatin on mesangial cells. Kidney Int 66:187195. doi:10.1111/j.1523-1755.2004.00710.x

Ikawa Y, Ng PS, Endo K, Kondo M, Chujo S, Ishida W, Shirasaki F, Fujimoto M, Takehara K (2008) Neutralizing monoclonal antibody to human connective tissue growth factor ameliorates transforming growth factor-beta-induced mouse fibrosis. J Cell Physiol 216:680-687. doi:10.1002/jcp. 21449

Ikeuchi H, Kuroiwa T, Yamashita S, Hiramatsu N, Maeshima A, Kaneko Y, Hiromura K, Ueki K, Nojima Y (2004) Fluvastatin Reduces Renal Fibroblast Proliferation and Production of Type III Collagen: Therapeutic Implications for Tubulointerstitial
Fibrosis. Nephron, Exp Nephrol 97:E115-E122. doi:10.1159/ 000079176

Ivkovic S, Yoon BS, Popoff SN, Safadi FF, Libuda DE, Stephenson RC, Daluiski A, Lyons KM (2003) Connective tissue growth factor coordinates chondrogenesis and angiogenesis during skeletal development. Development 130:2779-2791. doi:10.1242/ dev.00505

Kanemoto K, Usui J, Tomari S, Yokoi H, Mukoyama M, Aten J, Weening JJ, Nagata M (2003) Connective tissue growth factor participates in scar formation of crescentic glomerulonephritis. Lab Invest 83:1615-1625. doi:10.1097/01.LAB.0000096711. 58115.46

Karger A, Fitzner B, Brock P, Sparmann G, Emmrich J, Liebe S, Jaster R (2008) Molecular insights into connective tissue growth factor action in rat pancreatic stellate cells. Cell Signal 20:18651872. doi:10.1016/j.cellsig.2008.06.016

Kawaki H, Kubota S, Suzuki A, Lazar N, Yamada T, Matsumura T, Ohgawara T, Maeda T, Perbal B, Lyons KM, Takigawa M (2008a) Cooperative regulation of chondrocyte differentiation by CCN2 and CCN3 shown by a comprehensive analysis of the CCN family proteins in cartilage. J Bone Miner Res 23:17511764. doi:10.1359/jbmr.080615

Kawaki H, Kubota S, Suzuki A, Yamada T, Matsumura T, Mandai T, Yao M, Maeda T, Lyons KM, Takigawa M (2008b) Functional requirement of $\mathrm{CCN} 2$ for intramembranous bone formation in embryonic mice. Biochem Biophys Res Commun 366:450-456. doi:10.1016/j.bbrc.2007.11.155

Kennedy L, Liu S, Shi-Wen X, Chen Y, Eastwood M, Sabetkar M, Carter DE, Lyons KM, Black CM, Abraham DJ, Leask A (2007) $\mathrm{CCN} 2$ is necessary for the function of mouse embryonic fibroblasts. Exp Cell Res 313:952-964. doi:10.1016/j.yexcr. 2006.12.006

Koepke ML, Weber M, Schulze-Lohoff E, Beirowski B, Segerer S, Gross O (2007) Nephroprotective effect of the HMG-CoAreductase inhibitor cerivastatin in a mouse model of progressive renal fibrosis in Alport syndrome. Nephrol Dial Transplant 22:1062-1069. doi:10.1093/ndt/gf1810

Kothapalli D, Frazier KS, Welply A, Segarini PR, Grotendorst GR (1997) Transforming growth factor beta induces anchorageindependent growth of NRK fibroblasts via a connective tissue growth factor-dependent signaling pathway. Cell Growth Differ 8:61-68

Kothapalli D, Hayashi N, Grotendorst GR (1998) Inhibition of TGFbeta-stimulated CTGF gene expression and anchorage- independent growth by cAMP identifies a CTGF-dependent restriction point in the cell cycle. FASEB J 12:1151-1161

Kuiper EJ, Roestenberg P, Ehlken C, Lambert V, van Treslong-de Groot HB, Lyons KM, Agostini HJ, Rakic JM, Klaassen I, Van Noorden CJ, Goldschmeding R, Schlingemann RO (2007) Angiogenesis is not impaired in connective tissue growth factor (CTGF) knock-out mice. J Histochem Cytochem 55:1139-1147. doi:10.1369/jhc.7A7258.2007

Kuiper EJ, van Zijderveld R, Roestenberg P, Lyons KM, Goldschmeding R, Klaassen I, Van Noorden CJ, Schlingemann RO (2008) Connective tissue growth factor is necessary for retinal capillary basal lamina thickening in diabetic mice. J Histochem Cytochem 56:785-792. doi:10.1369/jhc.2008.950980

Kunzmann S, Schmidt-Weber C, Zingg JM, Azzi A, Kramer BW, Blaser K, Akdis CA, Speer CP (2007) Connective tissue growth factor expression is regulated by histamine in lung fibroblasts: Potential role of histamine in airway remodeling. J Allergy Clin Immunol 119:1398-1407. doi:10.1016/j.jaci.2007.02.018

Lawrencia C, Brigstock DR (2008) Targeted delivery of connective tissue growth factor siRNA to activated hepatic stellate cells resolves experimental liver fibrosis in mice. Hepatology 48:908A

Lawrencia C, Charrier A, Huang G, Brigstock DR (2009) Ethanolmediated expression of connective tissue growth factor (CCN2) 
in mouse pancreatic stellate cells. Growth Factors 27:91-99. doi:10.1080/08977190902786319

Leask A (2008) The Starbuck stops here: it's a Smad world. J Cell Commun Signal 2:1-2. doi:10.1007/s12079-008-0025-3

Leask A, Abraham DJ (2003) The role of connective tissue growth factor, a multifunctional matricellular protein, in fibroblast biology. Biochem Cell Biol 81:355-363. doi:10.1139/o03-069

Leask A, Abraham DJ (2004) TGF-beta signaling and the fibrotic response. FASEB J 18:816-827. doi:10.1096/fj.03-1273rev

Leask A, Chen S, Pala D, Brigstock DR (2008) Regulation of CCN2 mRNA expression and promoter activity in activated hepatic stellate cells. J Cell Commun Signal 2:49-56. doi:10.1007/ s12079-008-0029-z

Leask A, Holmes A, Abraham DJ (2002) Connective tissue growth factor: a new and important player in the pathogenesis of fibrosis. Curr Rheumatol Rep 4:136-142. doi:10.1007/s11926-002-0009-x

Leask A, Holmes A, Black CM, Abraham DJ (2003) CTGF gene regulation: Requirements for its induction by TGFbeta 2 in fibroblasts. $\mathrm{J}$ Biol Chem 278:13008-13015. doi:10.1074/jbc.M210366200

Leask, A., Parapuram, S. K., Shi-Wen, X. \& Abraham, D. J. (2009) Connective tissue growth factor $(\mathrm{CTGF}, \mathrm{CCN} 2)$ gene regulation: a potent clinical bio-marker of fibroproliferative disease? J Cell Commun Signal, doi: 10.1007/s12079-12009-10037-12077

Li C, Yang CW, Park JH, Lim SW, Sun BK, Jung JY, Kim SB, Kim YS, Kim J, Bang BK (2004) Pravastatin treatment attenuates interstitial inflammation and fibrosis in a rat model of chronic cyclosporine-induced nephropathy. Am J Physiol Renal Physiol 286:F46-F57. doi:10.1152/ajprenal.00428.2002

Li G, Li D, Xie Q, Shi Y, Jiang S, Jin Y (2008) RNA interfering connective tissue growth factor prevents rat hepatic stellate cell activation and extracellular matrix production. J Gene Med 10:1039-1047. doi:10.1002/jgm.1223

Li G, Xie Q, Shi Y, Li D, Zhang M, Jiang S, Zhou H, Lu H, Jin Y (2006) Inhibition of connective tissue growth factor by siRNA prevents liver fibrosis in rats. J Gene Med 8:889-900. doi:10.1002/jgm.894

Liang Y, Li C, Guzman VM, Evinger AJ 3rd, Protzman CE, Krauss $\mathrm{AH}$, Woodward DF (2003) Comparison of Prostaglandin F2 \{alpha\}, Bimatoprost (Prostamide), and Butaprost (EP2 Agonist) on Cyr61 and Connective Tissue Growth Factor Gene Expression. J Biol Chem 278:27267-27277. doi:10.1074/jbc.M301009200

Lin J, Liliensiek B, Kanitz M, Schimanski U, Bohrer H, Waldherr R, Martin E, Kauffmann G, Ziegler R, Nawroth PP (1998) Molecular cloning of genes differentially regulated by TNFalpha in bovine aortic endothelial cells, fibroblasts and smooth muscle cells. Cardiovasc Res 38:802-813. doi:10.1016/S00086363(98)00055-8

Liu X, Luo F, Pan K, Wu W, Chen H (2007) High glucose upregulates connective tissue growth factor expression in human vascular smooth muscle cells. BMC Cell Biol 8:1. doi:10.1186/14712121-8-1

Luo GH, Lu YP, Song J, Yang L, Shi YJ, Li YP (2008) Inhibition of connective tissue growth factor by small interfering RNA prevents renal fibrosis in rats undergoing chronic allograft nephropathy. Transplant Proc 40:2365-2369. doi:10.1016/j. transproceed.2008.07.100

Mageto Y, Flaherty K, Brown K, Fong A, Raghu G (2004) Safety and tolerability of human monoclonal antibody FG-3019, anticonnective tissue growth factor, in patients with idiopathic pulmonary fibrosis. Chest $126: 7735 \mathrm{a}$

Makino H, Mukoyama M, Sugawara A, Mori K, Suganami T, Yahata K, Fujinaga Y, Yokoi H, Tanaka I, Nakao K (2003) Roles of connective tissue growth factor and prostanoids in early streptozotocin-induced diabetic rat kidney: the effect of aspirin treatment. Clin Exp Nephrol 7:33-40. doi:10.1007/s101570300004
Marcelino J, McDevitt CA (1995) Attachment of articular cartilage chondrocytes to the tissue form of type VI collagen. Biochim Biophys Acta 1249:180-188

Martin J, Denver R, Bailey M, Krum H (2005) In vitro inhibitory effects of atorvastatin on cardiac fibroblasts: implications for ventricular remodelling. Clin Exp Pharmacol Physiol 32:697701. doi:10.1111/j.1440-1681.2005.04256.x

Mazaheri MK, Schultz GS, Blalock TD, Caffee HH, Chin GA (2003) Role of connective tissue growth factor in breast implant elastomer capsular formation. Ann Plast Surg 50:263-268. doi:10.1097/01.SAP.0000046781.75625.69

Meyer-Ter-Vehn T, Katzenberger B, Han H, Grehn F, Schlunck G (2008) Lovastatin inhibits TGF-beta-induced myofibroblast transdifferentiation in human tenon fibroblasts. Invest Ophthalmol Vis Sci 49:3955-3960. doi:10.1167/iovs.07-1610

Milam JE, Keshamouni VG, Phan SH, Hu B, Gangireddy SR, Hogaboam CM, Standiford TJ, Thannickal VJ, Reddy RC (2008) PPAR-gamma agonists inhibit profibrotic phenotypes in human lung fibroblasts and bleomycin-induced pulmonary fibrosis. Am J Physiol Lung Cell Mol Physiol 294:L891-L901. doi:10.1152/ajplung.00333.2007

Mori T, Kawara S, Shinozaki M, Hayashi N, Kakinuma T, Igarashi A, Takigawa M, Nakanishi T, Takehara K (1999) Role and interaction of connective tissue growth factor with transforming growth factor-beta in persistent fibrosis: A mouse fibrosis model. J Cell Physiol 181:153-159. doi:10.1002/(SICI)1097-4652 (199910) 181:1\&1t;153::AID-JCP16\&gt;3.0.CO;2-K

Mori Y, Hinchcliff M, Wu M, Warner-Blankenship M, Lyons KM, Varga J (2008) Connective tissue growth factor/CCN2-null mouse embryonic fibroblasts retain intact transforming growth factor-beta responsiveness. Exp Cell Res 314:1094-1104. doi:10.1016/j.yexcr.2007.12.010

Moriyama T, Nagatoya K (2004) The Rho-ROCK system as a new therapeutic target for preventing interstitial fibrosis. Drug News Perspect 17:29-34. doi:10.1358/dnp. 2004.17.1.829023

Nishida T, Kawaki H, Baxter RM, Deyoung RA, Takigawa M, Lyons KM (2007) CCN2 (Connective Tissue Growth Factor) is essential for extracellular matrix production and integrin signaling in chondrocytes. J Cell Commun Signal 1:45-58. doi:10.1007/s12079-007-0005-Z

Okada H, Kikuta T, Kobayashi T, Inoue T, Kanno Y, Takigawa M, Sugaya T, Kopp JB, Suzuki H (2005) Connective tissue growth factor expressed in tubular epithelium plays a pivotal role in renal fibrogenesis. J Am Soc Nephrol 16:133-143. doi:10.1681/ASN. 2004040339

Ostro MJ, Cullis PR (1989) Use of liposomes as injectable-drug delivery systems. Am J Hosp Pharm 46:1576-1587

Ou XM, Feng YL, Wen FQ, Huang XY, Xiao J, Wang K, Wang T (2008) Simvastatin attenuates bleomycin-induced pulmonary fibrosis in mice. Chin Med J (Engl) 121:1821-1829

Pala D, Kapoor M, Woods A, Kennedy L, Liu S, Chen S, Bursell L, Lyons KM, Carter DE, Beier F, Leask A (2008) Focal adhesion kinase/Src suppresses early chondrogenesis: central role of CCN2. J Biol Chem 283:9239-9247. doi:10.1074/jbc.M705175200

Pi L, Oh SH, Shupe T, Petersen BE (2005) Role of connective tissue growth factor in oval cell response during liver regeneration after 2-AAF/PHx in rats. Gastroenterology 128:2077-2088. doi:10.1053/j.gastro.2005.03.081

Pickles M, Leask A (2007) Analysis of CCN2 promoter activity in PANC-1 cells: regulation by ras/MEK/ERK. J Cell Commun Signal 1:85-90. doi:10.1007/s12079-007-0008-9

Prakash J, de Borst MH, van Loenen-Weemaes AM, Lacombe M, Opdam F, van Goor H, Meijer DK, Moolenaar F, Poelstra K, Kok RJ (2008) Cell-specific delivery of a transforming growth factorbeta type I receptor kinase inhibitor to proximal tubular cells for 
the treatment of renal fibrosis. Pharm Res 25:2427-2439. doi:10.1007/s11095-007-9515-x

Rachfal AW, Brigstock DR (2005) Structural and Functional Properties of CCN Proteins. Vitam Horm 70:69-103. doi:10.1016/ S0083-6729(05)70003-0

Ricupero DA, Rishikof DC, Kuang PP, Poliks CF, Goldstein RH (1999) Regulation of connective tissue growth factor expression by prostaglandin E(2). Am J Physiol 277:L1165-L1171

Ruperez M, Rodrigues-Diez R, Blanco-Colio LM, Sanchez-Lopez E, Rodriguez-Vita J, Esteban V, Carvajal G, Plaza JJ, Egido J, RuizOrtega M (2007) HMG-CoA reductase inhibitors decrease angiotensin II-induced vascular fibrosis: role of RhoA/ROCK and MAPK pathways. Hypertension 50:377-383. doi:10.1161/ HYPERTENSIONAHA.107.091264

Safadi FF, Xu J, Smock SL, Kanaan RA, Selim AH, Odgren PR, Marks SC Jr, Owen TA, Popoff SN (2003) Expression of connective tissue growth factor in bone: Its role in osteoblast proliferation and differentiation in vitro and bone formation in vivo. J Cell Physiol 196:51-62. doi:10.1002/jcp. 10319

Sakamoto N, Sugimura K, Kawashima H, Tsuchida K, Takemoto Y, Naganuma T, Tatsumi S, Nakatani T (2005) Influence of glucose and inflammatory cytokines on TGF-betal and CTGF mRNA expressions in human peritoneal mesothelial cells. Int J Mol Med 15:907-911

Sato Y, Murase K, Kato J, Kobune M, Sato T, Kawano Y, Takimoto R, Takada K, Miyanishi K, Matsunaga T, Takayama T, Niitsu Y (2008) Resolution of liver cirrhosis using vitamin A-coupled liposomes to deliver siRNA against a collagen-specific chaperone. Nat Biotechnol 26:431-442. doi:10.1038/nbt1396

Shi-Wen X, Leask A, Abraham D (2008) Regulation and function of connective tissue growth factor/CCN2 in tissue repair, scarring and fibrosis. Cytokine Growth Factor Rev 19:133-144. doi:10.1016/j.cytogfr.2008.01.002

Shi-wen X, Stanton LA, Kennedy L, Pala D, Chen Y, Howat SL, Renzoni EA, Carter DE, Bou-Gharios G, Stratton RJ, Pearson JD, Beier F, Lyons KM, Black CM, Abraham DJ, Leask A (2006) CCN2 is necessary for adhesive responses to transforming growth factor-betal in embryonic fibroblasts. J Biol Chem 281:10715-10726. doi:10.1074/jbc.M511343200

Shimo T, Kubota S, Yoshioka N, Ibaragi S, Isowa S, Eguchi T, Sasaki A, Takigawa M (2006) Pathogenic Role of Connective Tissue Growth Factor (CTGF/CCN2) in Osteolytic Metastasis of Breast Cancer. J Bone Miner Res 21:1045-1059. doi:10.1359/jbmr. 060416

Shimo T, Nakanishi T, Nishida T, Asano M, Sasaki A, Kanyama M, Kuboki T, Matsumura T, Takigawa M (2001) Involvement of CTGF, a hypertrophic chondrocyte-specific gene product, in tumor angiogenesis. Oncology 61:315-322. doi:10.1159/ 000055339

Song Y, Li C, Cai L (2004) Fluvastatin prevents nephropathy likely through suppression of connective tissue growth factor-mediated extracellular matrix accumulation. Exp Mol Pathol 76:66-75. doi:10.1016/j.yexmp. 2003.08.002

Stratton R, Rajkumar V, Ponticos M, Nichols B, Shiwen X, Black CM, Abraham DJ, Leask A (2002) Prostacyclin derivatives prevent the fibrotic response to TGF-beta by inhibiting the Ras/ MEK/ERK pathway. FASEB J 16:1949-1951

Stratton R, Shiwen X, Martini G, Holmes A, Leask A, Haberberger T, Martin GR, Black CM, Abraham D (2001) Iloprost suppresses connective tissue growth factor production in fibroblasts and in the skin of scleroderma patients. J Clin Invest 108:241-250

Sun K, Wang Q, Huang XH (2006) PPAR gamma inhibits growth of rat hepatic stellate cells and TGF beta-induced connective tissue growth factor expression. Acta Pharmacol Sin 27:715-723. doi:10.1111/j.1745-7254.2006.00299.x
Tong ZY, Brigstock DR (2005) Hepatic inflammation and fibrosis in transgenic mice that over-produce hepatocyte connective tissue growth factor. Hepatology 42(Suppl 1):A1031

Tong ZY, Brigstock DR (2006) Intrinsic biological activity of the thrombospondin structural homology repeat in connective tissue growth factor. J Endocrinol 188:R1-R8. doi:10.1677/joe.1.06719

Uchio K, Graham M, Dean NM, Rosenbaum J, Desmouliere A (2004) Down-regulation of connective tissue growth factor and type I collagen mRNA expression by connective tissue growth factor antisense oligonucleotide during experimental liver fibrosis. Wound Repair Regen 12:60-66

Verrecchia F, Mauviel A (2007) Transforming growth factor-beta and fibrosis. World J Gastroenterol 13:3056-3062

Vieira JM Jr, Mantovani E, Rodrigues LT, Delle H, Noronha IL, Fujihara CK, Zatz R (2005) Simvastatin attenuates renal inflammation, tubular transdifferentiation and interstitial fibrosis in rats with unilateral ureteral obstruction. Nephrol Dial Transplant 20:1582-1591. doi:10.1093/ndt/gfh859

Wang H, Dan Z, Jiang H (2008) Effect of all-trans retinoic acid on liver fibrosis induced by common bile duct ligation in rats. J Huazhong Univ Sci Technolog Med Sci 28:553-557

Wang JF, Olson ME, Ma L, Brigstock DR, Hart DA (2004a) Connective tissue growth factor siRNA modulates mRNA levels for a subset of molecules in normal and TGF-beta 1-stimulated porcine skin fibroblasts. Wound Repair Regen 12:205-216. doi:10.1111/j.1067-1927.2004.012113.x

Wang Q, Guo G, Liu D, Zhang W, Usinger W, Li D, Brenner M, Yeowell D, Lin A (2004b) Amelioration of diabetic nephropathy (DN) induced by renal ischemia-reperfusion (IR) in rats with diabetes mellitus (DM) by treatment with FG-3019, a monoclonal antibody against connective tissue growth factor (CTGF). J Am Soc Nephrol 15:737A

Wang W, Liu F, Chen N (2007) Peroxisome proliferator-activated receptor-gamma (PPAR-gamma) agonists attenuate the profibrotic response induced by TGF-betal in renal interstitial fibroblasts. Mediators Inflamm 2007:62641

Watts KL, Sampson EM, Schultz GS, Spiteri MA (2005) Simvastatin inhibits growth factor expression and modulates profibrogenic markers in lung fibroblasts. Am J Respir Cell Mol Biol 32:290 300. doi:10.1165/rcmb.2004-0127OC

Watts KL, Spiteri MA (2004) Connective tissue growth factor expression and induction by transforming growth factor-beta is abrogated by simvastatin via a Rho signaling mechanism. Am J Physiol Lung Cell Mol Physiol 287:L1323-L1332. doi:10.1152/ ajplung.00447.2003

Wei JL, Ma CY, Zhang YD, Li Y (2007a) Synergistic effects of pravastatin and pioglitazone in renal tubular epithelial cells induced by transforming growth factor-beta1. Cell Biol Int 31:451-458. doi:10.1016/j.cellbi.2006.11.008

Wei JL, Peng YM, Liu F (2007b) Connective tissue growth factor and fibronectin secretion in renal tubular epithelial cells induced by TGF-beta1: suppressive effects of troglitazone. Cell Biol Int 31:30-34. doi:10.1016/j.cellbi.2006.09.004

Xiao R, Kanekura T, Yoshida N, Higashi Y, Yan KL, Fukushige T, Kanzaki T (2008) 9-Cis-retinoic acid exhibits antifibrotic activity via the induction of cyclooxygenase-2 expression and prostaglandin E2 production in scleroderma fibroblasts. Clin Exp Dermatol 33:484-490. doi:10.1111/j.1365-2230.2008.02727.X

Xiao R, Liu FY, Luo JY, Yang XJ, Wen HQ, Su YW, Yan KL, Li YP, Liang YS (2006) Effect of small interfering RNA on the expression of connective tissue growth factor and type I and III collagen in skin fibroblasts of patients with systemic sclerosis. Br J Dermatol 155:1145-1153. doi:10.1111/j.1365-2133.2006.07438.x

Xie S, Sukkar MB, Issa R, Oltmanns U, Nicholson AG, Chung KF (2005) Regulation of TGF-beta1-induced connective tissue 
growth factor expression in airway smooth muscle cells. Am J Physiol Lung Cell Mol Physiol 288:L68-L76. doi:10.1152/ ajplung.00156.2004

Yamanaka O, Miyazaki K, Kitano A, Saika S, Nakajima Y, Ikeda K (2009) Suppression of injury-induced conjunctiva scarring by peroxisome proliferator-activated receptor gamma gene transfer in mice. Invest Ophthalmol Vis Sci 50:187-193. doi:10.1167/ iovs. $08-2282$

Yamanaka O, Saika S, Ikeda K, Miyazaki K, Kitano A, Ohnishi Y (2008) Connective tissue growth factor modulates extracellular matrix production in human subconjunctival fibroblasts and their proliferation and migration in vitro. Jpn J Ophthalmol 52:8-15. doi:10.1007/s10384-007-0497-3

Yokoi H, Mukoyama M, Mori K, Kasahara M, Suganami T, Sawai K, Yoshioka T, Saito Y, Ogawa Y, Kuwabara T, Sugawara A, Nakao $\mathrm{K}$ (2008) Overexpression of connective tissue growth factor in podocytes worsens diabetic nephropathy in mice. Kidney Int 73:446-455. doi:10.1038/sj.ki.5002722

Yokoi H, Mukoyama M, Nagae T, Mori K, Suganami T, Sawai K, Yoshioka T, Koshikawa M, Nishida T, Takigawa M, Sugawara A, Nakao K (2004) Reduction in connective tissue growth factor by antisense treatment ameliorates renal tubulointerstitial fibrosis. J Am Soc Nephrol 15:1430-1440. doi:10.1097/01.ASN. 0000130565.69170 .85
Yokoi H, Mukoyama M, Sugawara A, Mori K, Nagae T, Makino H, Suganami T, Yahata K, Fujinaga Y, Tanaka I, Nakao K (2002) Role of connective tissue growth factor in fibronectin expression and tubulointerstitial fibrosis. Am J Physiol Renal Physiol 282: F933-F942

Yokoi H, Sugawara A, Mukoyama M, Mori K, Makino H, Suganami T, Nagae T, Yahata K, Fujinaga Y, Tanaka I, Nakao K (2001) Role of connective tissue growth factor in profibrotic action of transforming growth factor-beta: a potential target for preventing renal fibrosis. Am J Kidney Dis 38:S134-S138. doi:10.1053/ ajkd.2001.27422

Yu J, Prado GN, Schreiber B, Polgar P, Taylor L (2002) Role of prostaglandin E(2) EP receptors and cAMP in the expression of connective tissue growth factor. Arch Biochem Biophys 404:302-308. doi:10.1016/S0003-9861(02)00276-X

Yuhua Z, Wanhua R, Chenggang S, Jun S, Yanjun W, Chunqing Z (2008) Disruption of connective tissue growth factor by short hairpin RNA inhibits collagen synthesis and extracellular matrix secretion in hepatic stellate cells. Liver Int 28:632-639

Zheng S, Chen A (2006) Curcumin suppresses the expression of extracellular matrix genes in activated hepatic stellate cells by inhibiting gene expression of connective tissue growth factor. Am J Physiol Gastrointest Liver Physiol 290:G883-G893. doi:10.1152/ajpgi.00450.2005 